\title{
PHYTOCHEMICAL SCREENING, ANTIOXIDANT, ANTIMICROBIAL, AND ANTIBIOFILM ACTIVITY OF SAUROPUS ANDROGYNUS LEAF EXTRACTS
}

\author{
SUJITHA KUTTINATH ${ }^{1}$, HARITHA KH ${ }^{1}$, RAM RAMMOHAN ${ }^{2 *}$ \\ ${ }^{1}$ Department of Microbiology, Nehru Arts and Science College, Coimbatore - 641 105, Tamil Nadu, India. ${ }^{2}$ Division of Laboratory \\ Services, Aravind Eye Hospital and Post-Graduate Institute of Ophthalmology, Coimbatore - 641 014, Tamil Nadu, India. \\ Email: ramrammohan2004@yahoo.com
}

Received: 26 January 2019, Revised and Accepted: 14 March 2019

ABSTRACT

Objective: The objective of the study was to perform phytochemical screening, and evaluate the antioxidant, antimicrobial, and antibiofilm activities of Sauropus androgynus leaf extract against pathogenic organisms.

Methods: Sauropus androgynus leaves were shade dried, powdered, and extracted by Soxhlet hot extraction procedure using ethanol or methanol. The aqueous extract was prepared using a rotary shaker. The qualitative phytochemical screening was carried out by gas chromatography-mass spectroscopic (GC-MS) analysis and liquid chromatography-mass spectrometry (LC-MS). The antioxidant activity of plant extracts was estimated by using 2,2-diphenyl-1-picrylhydrazyl (DPPH)-free radical scavenging assay. Antimicrobial and antibiofilm activity of extracts against various pathogens was performed using serial microdilution assay and microtiter plate method, respectively.

Results: Preliminary phytochemical analysis showed the presence of compounds such as tannins, flavonoids, alkaloids, and phenols. GC-MS studies also revealed the presence of biologically active compounds. Methanolic extract of $S$. androgynus showed higher DPPH Scavenging activity compared to other extracts. All the extracts were able to inhibit both bacterial growth and biofilm production; however, the methanolic extract showed the highest antibiofilm activity.

Conclusion: S. androgynus plant extracts possess significant antioxidant, antimicrobial, and antibiofilm activity.

Keywords: Sauropus androgynus, Extracts, Gas chromatography-mass spectroscopic, Minimum inhibitory concentration, Biofilm.

(C) 2019 The Authors. Published by Innovare Academic Sciences Pvt Ltd. This is an open access article under the CC BY license (http://creativecommons. org/licenses/by/4. 0/) DOI: http://dx.doi.org/10.22159/ajpcr.2019.v12i4.31756

\section{INTRODUCTION}

India is famous for its ancient heritage of using medicinal plants in traditional medicines. Many years of efforts in the search for good health, longevity, as well as for remedies to pain and discomfort, have led to the discovery of a variety of ethnomedicines. Plants are used as medicines in different systems of medicine including Ayurveda, Unani, Allopathy, and Homoeopathy [1,2]. From these medicinal plants, many new therapeutically effective drugs have been discovered and formulated as anticancer drugs or antimicrobials [3-6]. The use of plants for healing and as a source for antimicrobials has considerable advantages over current chemotherapeutic approaches [6,7]. Studies reveal that many medicinal plants are a good source of bioactive compounds such as peptides, glycosides, alkaloids, saponins, terpenoids, flavonoids, and phenols (most of which have antimicrobial activity) to treat microbial infections [8-11]. Antibiotic resistance of pathogens and the drastic side effects of antibiotic use have stimulated the search for new medicinal/ bioactive compounds, especially from plants [12]. Resistance to antimicrobials can be caused by a variety of mechanisms, including biofilm formation. Various plant-based chemicals have been tested for their antibiofilm activity, and the alternative use of natural antibiofilm agents has gained importance $[13,14]$. Studies have shown the effect of plant extracts in preventing biofilm formation or inhibiting adherence of pathogenic microorganisms $[15,16]$. Plant-derived compounds have been found to have potential applications in pharmaceuticals, due to safety and less-toxicity properties [14-17].

Sauropus androgynus is known as Multivitamin Plant, and it is a good source of Vitamins A, B, C, and K, as well as carotenoids. Various parts of $S$. androgynus are commonly used to treat fever, diabetes, cancer, high cholesterol, allergies, urinary tract infections, and earaches [18-20].
Extracts of these medicinal plants are most often utilized for the preparation of raw drugs since their various medicinal properties could be due to additive or synergistic activity [12]. A survey of the literature reveals that so far, no studies have been reported about the antibiofilm activity of $S$. androgynus leaves extracts. Thus, the present research work was designed to evaluate the phytochemical constituents, antioxidant, antimicrobial, and antibiofilm activities of $S$. androgynus leaf extracts.

\section{METHODS}

Plant collection and extraction

The fresh leaves of $S$. androgynus were collected from Palakkad, South India. The plant with complete herbarium was identified (No.BSI/ SRC/5/23/2016/Tech/1336) and authenticated at the Botanical Survey of India, Coimbatore, Tamil Nadu, India. Collected leaves were washed thoroughly under tap water, detergent water, and finally rinsed with distilled water until no foreign materials remained (Damaged leaves were removed). The leaves were then dried under shade for 10 days. The dried leaves were pulverized using a sterile electric grinder to obtain a powdered form. The powdered samples were stored in airtight containers, protected from sunlight until required for further use.

The powdered leaves ( $25 \mathrm{~g}$ ) were continuously extracted with different solvents, namely methanol, ethanol, or distilled water, for successive solvent extraction based on their polarity. The Soxhlet hot extraction procedure for methanol and ethanol solvents was performed for 12-16 $\mathrm{h}$ or until the color of the extracted solvent became clear [21]. The aqueous extract was prepared by soaking the plant powder in distilled water (plant powder to solvent ratio of $1: 10 \mathrm{w} / \mathrm{v}$ ) and extracted using Rotary shaker at $150 \mathrm{rpm}$ for $24 \mathrm{~h}$ at room temperature [22]. The methanolic extracts of $S$. androgynus leaves (SALM), ethanolic extract 
of $S$. androgynus leaves (SALE), and aqueous extracts of $S$. androgynus leaves (SALA) were concentrated under reduced pressure using a rotary vacuum evaporator. The extracts were then transferred into vials, dried in a desiccating chamber, and stored in an air-tight container at low temperature $\left(@ 4^{\circ} \mathrm{C}\right)$. The extracts were dissolved in dimethyl sulfoxide (DMSO) to prepare stock solutions for further studies.

\section{Preliminary phytochemical analysis}

Qualitative phytochemical analysis of SALM, SALE, and SALA was performed for the identification of flavonoids, tannins, terpenoids, and alkaloids according to the standard methods [23]. The extracts were screened for the presence of various bioactive compounds including alkaloids, flavonoids, phenols, and tannins.

\section{Gas chromatography-mass spectroscopic (GC-MS) analysis}

Analytical techniques such as GC-MS are considered a powerful tool for the identification of secondary metabolites present in the plant extracts. Compounds such as essential oils, alcohols, acids, esters, steroids, amino, and nitro compounds can be identified using GC-MS. The phytochemical compounds present in the extracts of SALM and SALE were identified and confirmed using a Shimadzu GC-MS (Model Number: QP2010S equipped with Rxi-5Sil MS column) [24,25]. The plant extracts diluted in respective solvents were injected in splitless mode at an injector temperature of $260^{\circ} \mathrm{C}$. The interface temperature was set at $280^{\circ} \mathrm{C}$, and the oven temperature of the column was raised from $80^{\circ} \mathrm{C}$ to $260^{\circ} \mathrm{C}$ at $10^{\circ} \mathrm{C} / \mathrm{min}$. The phytochemical constituents were identified and compared based on the retention time, using the National Institute of Standards and Technology Mass Spectral Database (NIST 11), and the WILEY 8 library [26,27].

\section{Characterization of SALA extract by liquid chromatography-mass spectrometry (LC-MS)}

LC-MS analysis can be used to identify the fragmentation and structural information of both known and unknown compounds present in a sample [28]. The LC-MS analysis of SALA extract was carried out with the Waters Acquity $\mathrm{H}$ class ultra-performance LC BEH C18 column (50 mm×2.1 mm $\times 1.7 \mu \mathrm{m}$; Waters India Pvt., Ltd., Bengaluru, India) in the Waters Xevo G2 Q-TOF mass spectrophotometer with Mass V 4.1 software. The compounds were identified by comparing with MS/MS Spectra using the ChemSpider database [29].

\section{Antioxidant assay (2,2-diphenyl-1-picrylhydrazyl [DPPH]-free radical scavenging activity)}

The antioxidant activity of all the extracts was determined based on hydrogen donation or radical scavenging ability using the DPPH assay, according to the standard protocol [30]. Samples (plant extracts) and standard (ascorbic acid) were taken at various concentrations, and the final volume was adjusted to $100 \mu \mathrm{L}$ using methanol. The aliquots of samples were added to $3 \mathrm{ml}$ of a $0.01 \mathrm{mM}$ methanolic solution and mixed well. The negative control was also prepared by adding $100 \mu \mathrm{L}$ of methanol in $3 \mathrm{ml}$ of $0.1 \mathrm{mM}$ methanolic solution of DPPH. The tubes were allowed to stand in dark for $30 \mathrm{~min}$ at room temperature. After $30 \mathrm{~min}$, the absorbance of the sample was measured at $517 \mathrm{~nm}$ against the blank. The DPPH-free radical scavenging activity percentage was calculated using the following equation:

\section{DPPH scavenging activity $\%=[($ Control-Test sample $) /$ Control $] * 100$}

\section{Bacterial Isolates and culture media}

A total of four American Type Culture Collection (ATCC) (originally from ATCC, Virginia, USA) strains were used for testing antimicrobial activity. An additional five clinical strains and three ATCC reference strains were also used for the antibiofilm assay. All strains were maintained in glycerol and stored at low temperature. Strains were subcultured onto suitable medium and grown at $37^{\circ} \mathrm{C}$ for $24 \mathrm{~h}$ before any assay. In order to determine the minimum inhibitory concentration (MIC) against bacterial strains, Tryptic Soy Broth (TSB) was used, whereas brain heart infusion (BHI) broth supplemented with $2 \%$ sucrose was used for biofilm formation and antibiofilm activity assays.
MIC

The MIC values of SALM, SALE, and SALA extracts were determined using the serial microdilution method [31]. Briefly, $100 \mu \mathrm{L}$ of extracts from the stock solution $(10 \mathrm{mg} / \mathrm{ml})$ was added to the first row of a sterile 96-well polystyrene flat-bottom microtiter plate. Twofold serial dilution was performed using the first well-containing stock solution after the addition of $50 \mu \mathrm{L}$ of TSB to the remaining wells. Overnight bacterial culture developed from storage were resuspended in TSB and incubated at $37^{\circ} \mathrm{C}$ for $3 \mathrm{~h} .50 \mu \mathrm{L}$ of bacterial cells $\left(1.0-1.5 \times 10^{6} \mathrm{CFU} / \mathrm{ml}\right)$ were added to serially diluted wells of a microtiter plate, thereby making a final volume of $100 \mu \mathrm{L}$ each. Twofold dilutions of gentamycin and chloramphenicol were also included as positive controls. Bacterial cultures in TSB devoid of extracts were used as negative control. Wells filled with TSB alone were the blank reference. After incubation at $37^{\circ} \mathrm{C}$ for $24 \mathrm{~h}$ [32], to each well was added $40 \mu \mathrm{L}$ of $0.2 \mathrm{mg} / \mathrm{ml}$ of p-iodonitrotetrazolium violet salts solution (INT). The microtiter plates were allowed to stand at $37^{\circ} \mathrm{C}$ for $30 \mathrm{~min}$, and results were recorded. The formation of blue color on the wells indicates the presence of viable cells [33]. The MIC of extracts was determined visually as the lowest concentration which inhibited the bacterial growth. Each bioassay was carried out in triplicate.

\section{Biofilm phenotypic assay}

Biofilm production was determined using the standard Crystal Violet (CV) assay [34]. A total of 20 bacterial strains including 3 ATCC reference strains from fresh agar plates were inoculated into BHI broth (supplemented with $2 \%$ sucrose) and incubated for $18 \mathrm{~h}$ at $37^{\circ} \mathrm{C}$ in a stationary condition and diluted 1 in 100 with fresh medium. Individual wells of sterile, polystyrene, 96-well; flat-bottom microtiter plates were filled with $0.2 \mathrm{ml}$ aliquots of the diluted cultures (broth only served as the control). The microtiter plates were incubated for $18-24 \mathrm{~h}$ at $37^{\circ} \mathrm{C}$. After incubation, the plates were tapped gently to remove the content of each well. In order to remove the free-floating "planktonic" bacteria, the wells were washed 4 times with $0.2 \mathrm{ml}$ of phosphate-buffered saline. Sodium acetate $(2 \%)$ was used for fixing the biofilm formed by adherent "sessile" organisms in the plates. The plates were then stained with CV $(0.1 \% \mathrm{w} / \mathrm{v})$, and the excess stain was washed off thoroughly using deionized water. The plates were then allowed to dry. The quantification of biofilm production was carried out by the addition of $150 \mu \mathrm{L}$ of $95 \%$ ethanol to each of the wells. After keeping the plates at room temperature for $30 \mathrm{~min}$, the Optical Density (OD) of the stained adherent bacterial biofilms was read using a plate reader at $570 \mathrm{~nm}$. The experiment was performed in triplicate. The average OD value of test organisms and controls was calculated, and the standard deviation above negative control (OD at $570 \mathrm{~nm}$ ) was determined as cutoff value (ODc). The isolates were further divided in to non-biofilm producer $=O D \leq O D c(0)$, weak biofilm producer $=$ ODc $<\mathrm{OD} \leq 2 \times \mathrm{ODc}(+$ or 1$)$, moderate biofilm producer $=2 \times \mathrm{ODc}<\mathrm{OD} \leq 4$ $\times$ ODc $(++$ or 2$)$, and strong biofilm producer $=4 \times \mathrm{ODc}<\mathrm{OD}(+++$ or 3$)$.

\section{Effect of plant extract on biofilm formation}

The activity of SALM, SALE, and SALA extracts on inhibition of bacterial biofilm was performed using microtiter plate method modified from Stepanović et al., and O'Toole and Kolter [34,35]. Two-fold dilutions of SALM, SALE, and SALA extract stock solutions $(10 \mathrm{mg} / \mathrm{ml})$ were made in 96-well microtiter plates containing $50 \mu \mathrm{L}$ of BHI broth (supplemented with $2 \%$ sucrose) in all wells except the first well of each row. Growth controls (cells + BHI), media control (BHI only), and blank control (plant extract $+\mathrm{BHI}$ ) were also maintained. The plates were then incubated at $37^{\circ} \mathrm{C}$ for $48 \mathrm{~h}$. After incubation, the plates were subjected to $\mathrm{CV}$ assay as described above. The assay was carried out in triplicate. The percentage of specific biofilm inhibition [36] was calculated using the following formula:

Biofilm inhibition percentage $=[(\mathrm{OD}$ Growth control - OD test sample)/OD Growth control] $\times 100$ 


\section{RESULTS}

Qualitative phytochemical analysis

The qualitative phytochemical analysis of SALM, SALE, and SALA extracts showed the presence of various compounds, as listed in Table 1.

\section{GC-MS analysis}

Phytochemicals present in SALE, and SALM extracts was identified and matched using NIST 11 database and the Wiley 8 library. The names, peak area percentages, and biological activities of major phytochemicals present in SALM and SALE are listed in Fig. 1 and Table 2.

\section{LC-MS}

The total ion chromatogram of SALA extract is shown in Fig. 2. LC-MS analysis of SALA extract revealed the presence of several bioactive compounds. Further studies are needed to identify their structure and properties.

Table 1: Phytochemical analysis

\begin{tabular}{llll}
\hline Name of test & SALM & SALE & SALA \\
\hline Carbohydrates & + & + & + \\
Proteins & + & + & + \\
Tannins & + & + & + \\
Saponins & + & - & + \\
Alkaloids & + & + & + \\
Flavonoids & + & + & + \\
Terpenoids & + & - & + \\
Glycosides & + & + & + \\
Phenols & + & + & + \\
Steroids & - & + & + \\
\hline
\end{tabular}

+: For the presence; -: For the absence
Antioxidant activity

From the results, it has been noted that the free radical-scavenging activity of SALM, SALE, and SALA is concentration dependent. The results also show that SALM, SALE, and SALA possess potent antioxidant activity (Fig. 3).

\section{MIC of SALM, SALE, and SALA}

The MIC values of SALM, SALE, and SALA were calculated to evaluate their effect on four ATCC strains (Staphylococcus aureus ATCC 25923, Pseudomonas aeruginosa ATCC 27853, Escherichia coli ATCC 25922, and Proteus vulgaris NCIM 2027). SALM, SALE, and SALA were found to have a MIC value between $1.25 \mathrm{mg} / \mathrm{ml}$ and $5 \mathrm{mg} / \mathrm{ml}$ (Table 3). Plant extract at a concentration of $5 \mathrm{mg} / \mathrm{ml}$ was defined as the lowest concentration on inhibiting the growth of strains after incubation when compared to control. Chloramphenicol and gentamicin were used as reference antibiotics for Gram positive and Gram negative bacteria, respectively.

\section{Biofilm production by microtiter plate method}

All the 20 bacterial isolates were subjected to biofilm production on microtiter plates. After incubation, ODc values were determined. Of 17 clinical isolates, 2 strong biofilm producers (Acinetobacter baumannii and Pseudomonas stutzeri) and 3 moderate biofilm producers (methicillin-resistant S. aureus, Coagulase-negative Staphylococcus, and Bacillus species) were identified. Rest of the isolates were nonbiofilm producers. Among the 3 ATCC strains, 2 were strong (E. coli ATCC 25922, S. aureus ATCC 25923) and remaining one was a weak biofilm producer (P. aeruginosa ATCC 27853). Of 23 isolates subjected to biofilm production, 8 were selected for further studies (Table 4 ).

Antibiofilm activity of SALM, SALE, and SALA

The effect of plant extracts on biofilm inhibition was carried out in a microtiter plate. All three extracts were able to decrease biofilm

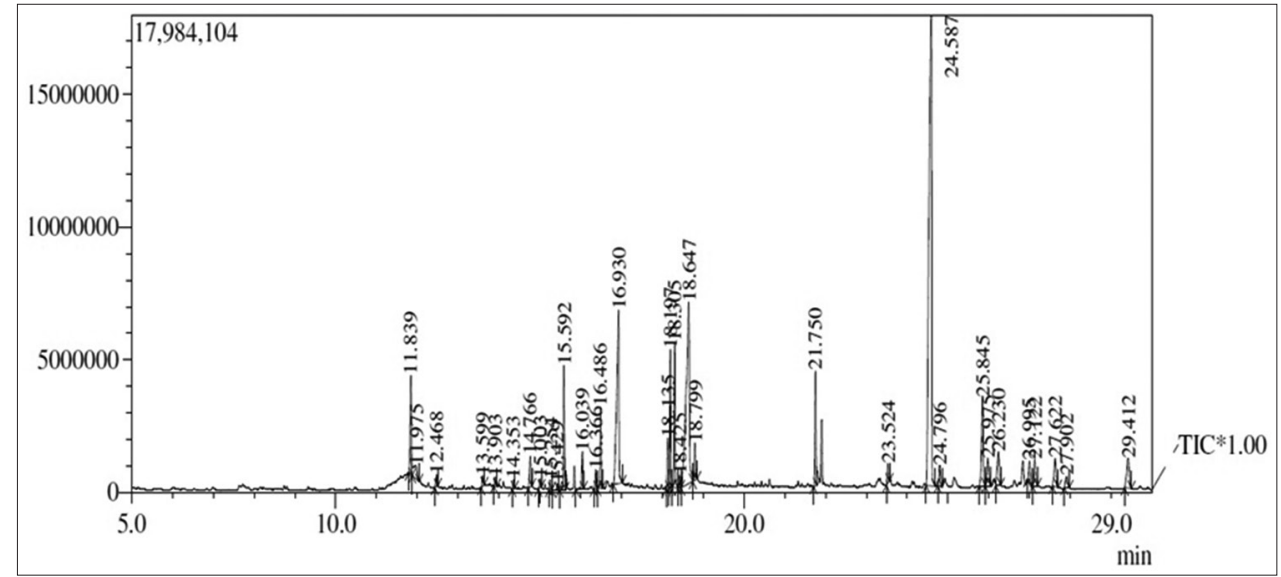

Fig. 1a: Gas chromatography-mass spectroscopic analysis of methanolic extracts of Sauropus androgynus leaves

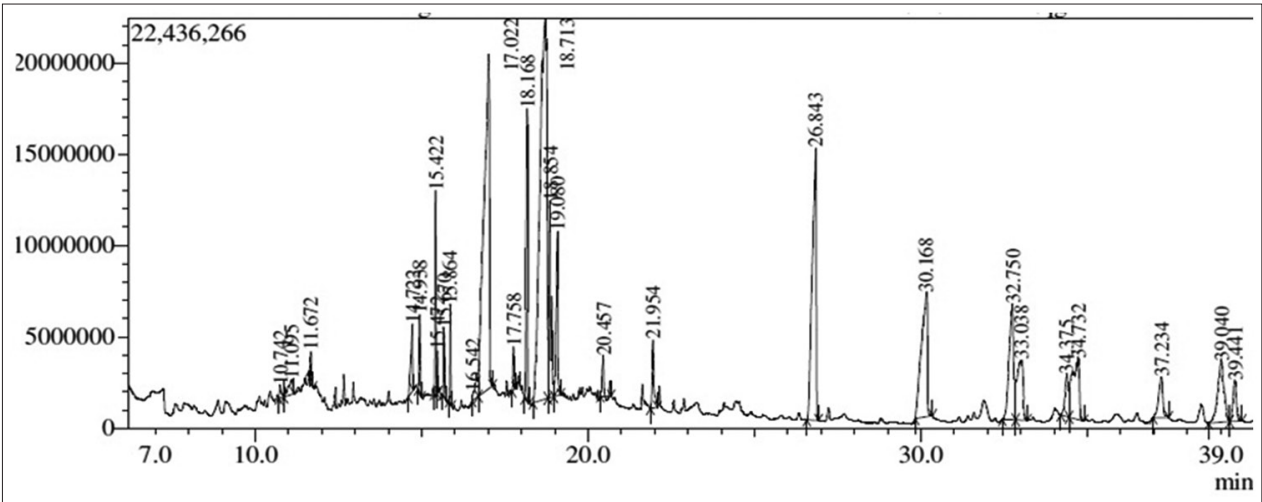

Fig. 1b: Gas chromatography-mass spectroscopic analysis of ethanolic extract of Sauropus androgynus leaves 
Table 2: Gas chromatography-mass spectroscopic analysis of SALM and SALE

\begin{tabular}{|c|c|c|c|c|}
\hline \multicolumn{5}{|l|}{ SALM } \\
\hline S. No & Retention time (min) & Compound name & Area\% & Biological activity [37-57] \\
\hline 1 & 24.587 & Squalene & 33.99 & $\begin{array}{l}\text { Antibacterial, antioxidant, anticancer, chemopreventive, } \\
\text { immunostimulant, lipoxygenase inhibitor }\end{array}$ \\
\hline 2 & 18.647 & Cis, cis, cis-7,10,13-Hexadecatrienal & 14.95 & Antioxidant activity \\
\hline 3 & 16.93 & Hexadecanoic Acid & 10.06 & $\begin{array}{l}\text { Antibacterial, nematicide, pesticide, lubricant, } \\
\text { antiandrogenic, hemolytic } 5 \text {-alpha reductase inhibitor, } \\
\text { anti-inflammatory, phospholipase inhibitor }\end{array}$ \\
\hline 4 & 25.845 & Solanesol & 4.09 & $\begin{array}{l}\text { Antimicrobial, antihypersensitive, cardiac stimulant and } \\
\text { lipid antioxidant, antitumor, anti-inflammatory, antiulcer }\end{array}$ \\
\hline 5 & 18.305 & Phytol & 3.97 & $\begin{array}{l}\text { Antimicrobial, anti-inflammatory, anticancer, antidiuretic, } \\
\text { immunostimulatory, antidiabetic }\end{array}$ \\
\hline 6 & 15.592 & Neophytadiene & 2.92 & $\begin{array}{l}\text { Bactericidal, antifungal, antipyretic, analgesic, antioxidant, } \\
\text { antihelminthic }\end{array}$ \\
\hline 7 & 11.839 & Phenol, 2,4-Bis (1,1-Dimethylethyl)- & 2.74 & Antibacterial, antioxidant \\
\hline \multicolumn{5}{|l|}{ SALE } \\
\hline 1 & 18.713 & 9,12,15-Octadecatrienoic acid, (Z, Z, Z) & 25.43 & $\begin{array}{l}\text { Anti-inflammatory, antifungal, antiacne, antihistaminic, } \\
\text { antieczemic, pesticide, antiarthritic, hypocholesterolemic, } \\
\text { nematicide }\end{array}$ \\
\hline 2 & 17.022 & Hexadecanoic acid, ethyl ester & 17.25 & $\begin{array}{l}\text { Antimicrobial, antioxidant, hypocholesterolemic, } \\
\text { nematicide, pesticide, antiandrogenic, hemolytic, alpha } \\
\text { reductase inhibitor. }\end{array}$ \\
\hline 3 & 26.843 & Squalene & 10.19 & $\begin{array}{l}\text { Antibacterial, antioxidant, antitumor, chemopreventive, } \\
\text { immunostimulant, lipoxygenase inhibitor. }\end{array}$ \\
\hline 4 & 30.168 & Delta.-tocopherol & 7.08 & Vitamin, antioxidant, anti-inflammatory \\
\hline 5 & 32.75 & Gamma.-Tocopherol & 5.15 & $\begin{array}{l}\text { Antioxidant, antitumor, anti-inflammatory, } \\
\text { hypocholesterolemic, cardioprotective. }\end{array}$ \\
\hline 6 & 18.854 & Octadecanoic acid & 3.68 & Antimicrobial \\
\hline
\end{tabular}

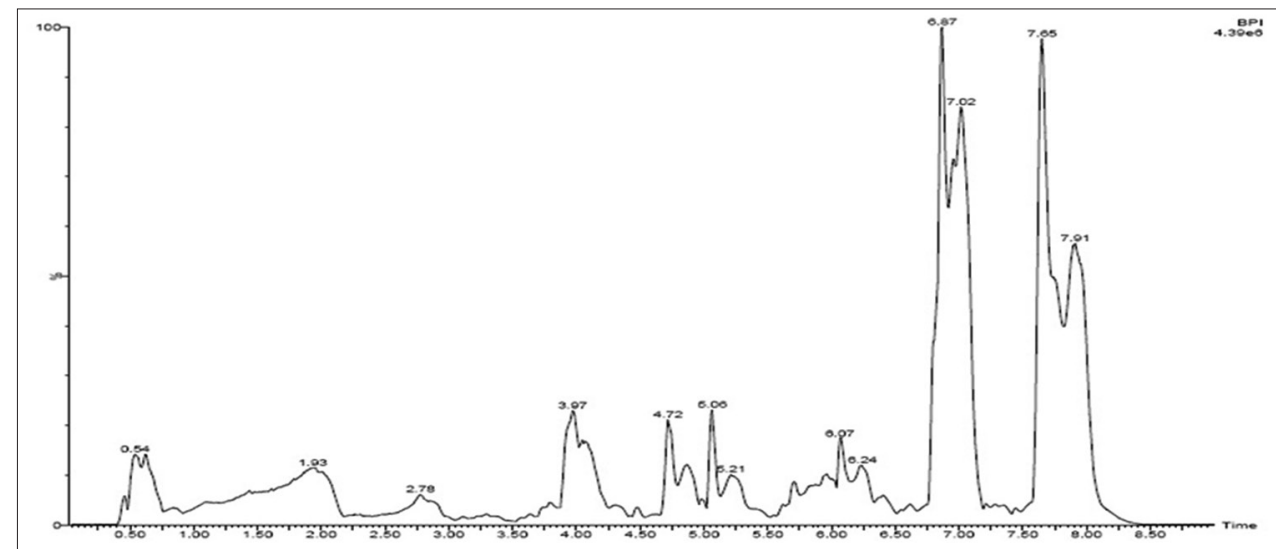

Fig. 2a: Liquid chromatography-mass spectrometry chromatographic profiles of SALA extract - Positive ion mode

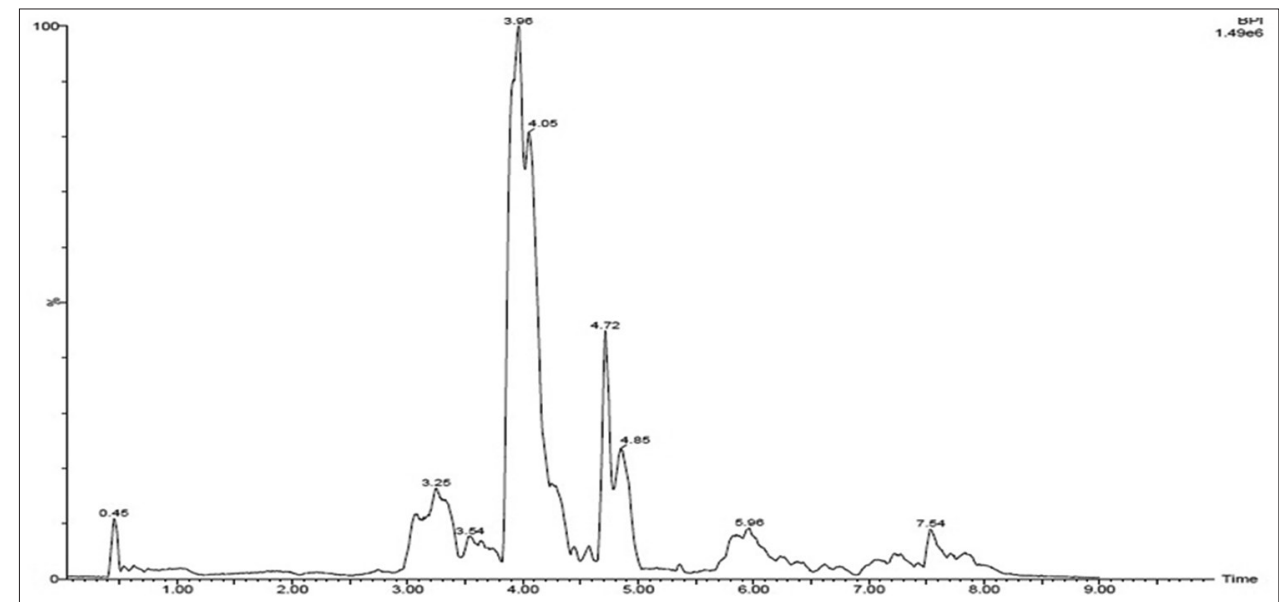

Fig. 2b: liquid chromatography-mass spectrometry chromatographic profiles of SALA extract - negative ion mode 
production. Biofilm inhibition percentage of each extract against bacterial strains was calculated. It was found that all of the extracts

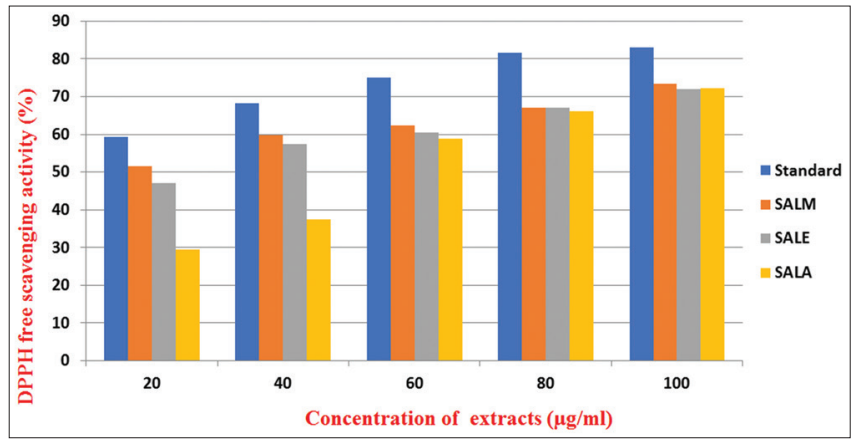

Fig. 3: 2,2-diphenyl-1-picrylhydrazyl activity of plant extracts at different concentrations were able to inhibit biofilm production. Among the extracts, SALM was found to possess the highest biofilm inhibition percentage against all biofilm producers (Fig. 4).

\section{DISCUSSION}

Plants are widely used to control common health complications as they possess several effective organic molecules called secondary metabolites. These bioactive compounds exhibit various pharmacological properties and are responsible for the medicinal activity of plants [58]. All the three extracts were found to have phytochemicals such as tannins, flavonoids, alkaloids, phenols, and steroids. The phytochemical tannins which are known for their astringent actions were identified in the plant extract. They are found to possess antimicrobial, antibacterial, antitumor, and antiviral activities [59-62]. GC-MS analysis showed that at least 15 compounds are present in both SALM and SALE. Squalene was the major compound identified in SALM extract whereas 9, 12, 15-Octadecatrienoic acid, $(\mathrm{Z}, \mathrm{Z}, \mathrm{Z})$ is the highest compound identified on SALE. Various compounds identified on GC-MS analysis are known

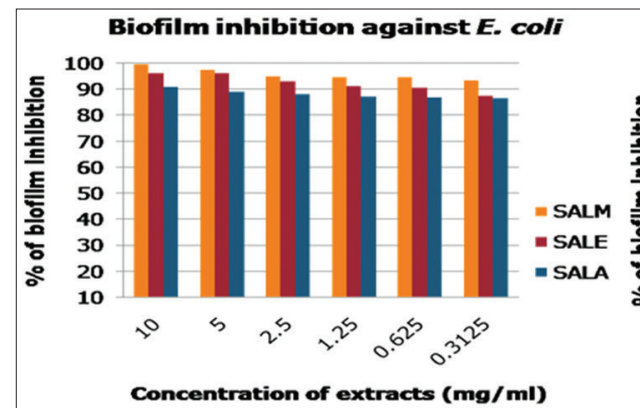

Biofilm inhibition against $S$, aureus

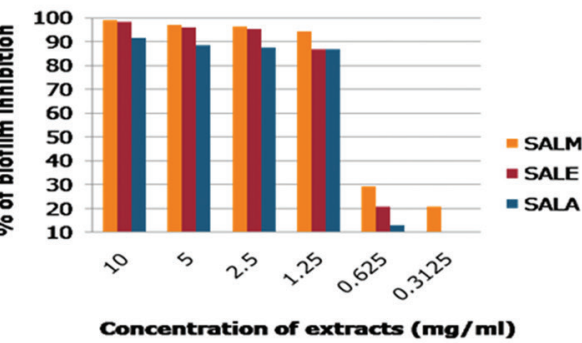

Biofilm inhibition against $P$. stutzeri
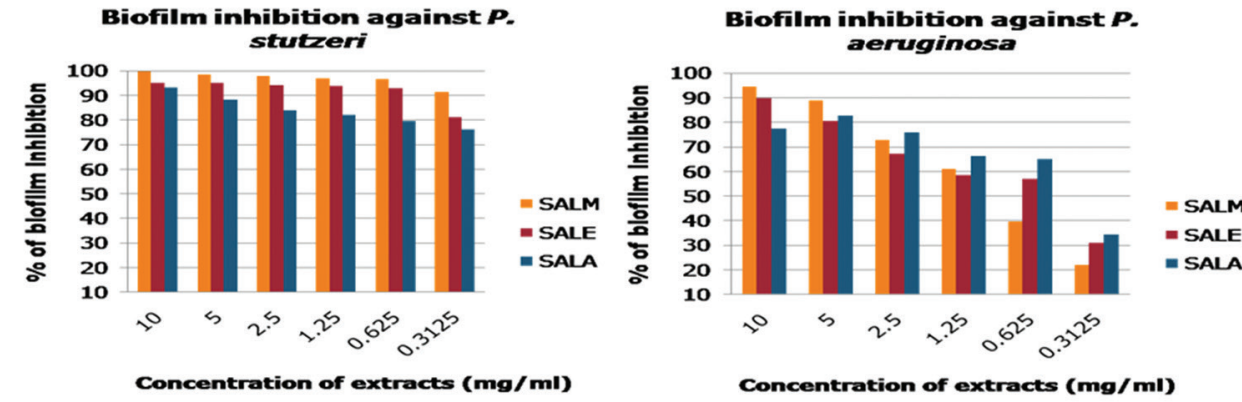

Biofilm inhibition against CoNS
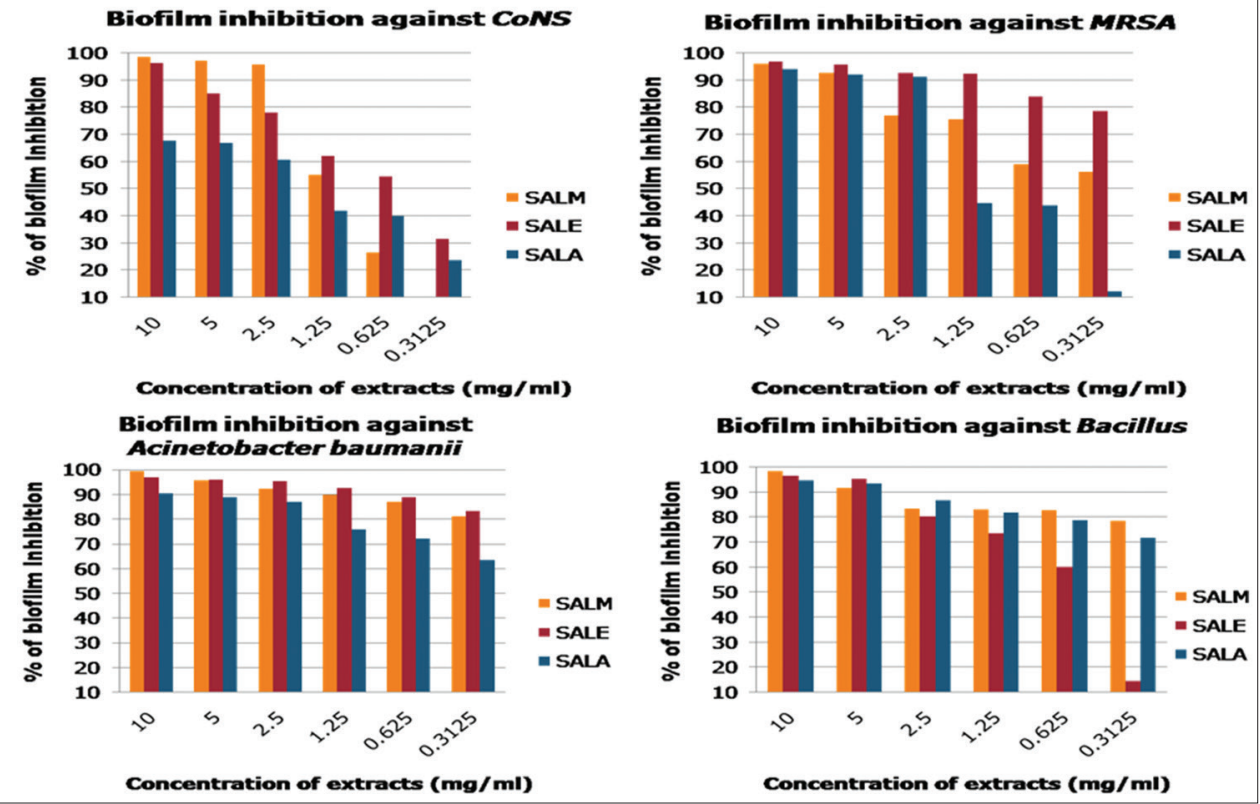

Fig. 4: Biofilm inhibition percentage of various extracts against bacterial strains 
Table 3: MIC of plant extracts against bacterial strains

\begin{tabular}{|c|c|c|c|c|c|c|}
\hline \multirow[t]{2}{*}{ S.No. } & \multirow[t]{2}{*}{ Bacterial strains } & \multicolumn{5}{|c|}{ MIC (mg/ml) } \\
\hline & & SALM & SALE & SALA & Chloramphenicol & Gentamicin \\
\hline 1 & S. aureus ATCC 25923 & 5 & 5 & 5 & 0.625 & - \\
\hline 3 & E. coli ATCC 25922 & 1.25 & 1.25 & 1.25 & - & ND* \\
\hline 4 & P. vulgaris NCIM 2027 & 1.25 & 1.25 & 1.25 & - & 0.625 \\
\hline
\end{tabular}

*ND: Not determined, MIC: Minimum inhibitory concentration, S. aureus: Staphylococcus aureus, P. aeruginosa: Pseudomonas aeruginosa, E. coli: Escherichia coli, P. vulgaris: Proteus vulgaris

Table 4: Biofilm production on a microtiter plate

\begin{tabular}{lllll}
\hline Isolates & Nonbiofilm producer $\mathbf{n}(\%)$ & Weak biofilm producer $\mathbf{n}(\%)$ & Moderate biofilm producer $\mathbf{n}(\%)$ & Strong biofilm producer $\mathbf{n}(\%)$ \\
\hline $\mathrm{n}=20$ & $12(60)$ & $1(5)$ & $3(15)$ & $4(20)$ \\
\hline
\end{tabular}

to possess antimicrobial, anticancer, anti-inflammatory, antifungal, antioxidant, and immunomodulatory properties $[63,64]$. In the current study, leaf extracts of $S$. androgynus exhibited both antimicrobial and antibiofilm activity. Bioactive compounds identified in SALM and SALE was found to be similar to those reported from previous studies [47]. Several studies reported the potential antioxidant activity of $S$. androgynus as well as its high flavonoid content $[47,65,66]$. All of the extracts were found to exhibit significant antioxidant properties compared to the standard. Among the extracts, SALM was found to have high antioxidant content which matches the findings of Badami and Channabasavaraj et al. [66]. Another experiment on DPPH scavenging activities of $S$. androgynus aqueous extract was found to have high polyphenol content and antioxidant activity [67]. The antibacterial activity of extracts could be due to the presence of multivitamins, peptides, glycosides, alkaloids, saponins, terpenoids, and flavonoids [68]. In the present study, antimicrobial activities of the extracts are in concordance with the findings of previous studies $[47,69]$. Furthermore, the MIC values of plant extract SALM, SALE, and SALA obtained against pathogenic strains at a concentration of $1.25-5 \mathrm{mg} / \mathrm{ml}$ were considered a promising result. Among the plant extracts screened, SALM was found to be a potential biofilm inhibitor compared to other extracts. SALM extracts were found to exhibit biofilm inhibition of 80-98\% against pathogenic bacterial strains. Previously published studies have reported $80 \%$ biofilm inhibition at $100 \mu \mathrm{g} / \mathrm{ml}$ using marine actinomycetes (CAA-3) [70]. Antibiofilm activity of $S$. androgynus has not been reported using methanolic, ethanolic, and aqueous extracts. We report the first study on the antibiofilm activity of SALM, SALE, and SALA against pathogenic strains.

\section{CONCLUSION}

Plants are excellent sources of bioactive and phenolic compounds, and they can be exploited for beneficial uses. SALM, SALE, and SALA which contain essential compounds can be utilized for antimicrobial and antibiofilm activities. Antipathogenic therapy which targets only the biofilm and its associated virulence rather than harming the growth of pathogen is an alternative strategy for currently prevailing antimicrobial therapy. These findings justify the consideration of S. androgynus plant extracts as a potential natural source of products for not only preventing biofilm formation but also for use as an antiseptic (or topical) in the prophylaxis and treatment of skin/wound infections.

\section{ACKNOWLEDGMENT}

The authors are thankful for the Head and Staff, Department of Microbiology, Nehru Arts and Science College, Coimbatore, India for their encouragement to carry out this study.

\section{AUTHORS CONTRIBUTION}

Sujitha Kuttinath: All fieldwork, laboratory experiments, and preparation of documents. Haritha KH: Supporting laboratory experiments. Ram
Rammohan: Guide, experimental designs, troubleshooting, preparation of the manuscript.

\section{CONFLICTS OF INTEREST}

The authors declare that they have no conflicts of interest.

\section{REFERENCES}

1. Balandrin MF, Klocke JA, Wurtele ES, Bollinger WH. Natural plant chemicals: Sources of industrial and medicinal materials. Science 1985; 228:1154-60.

2. Nautiyal S, Kumar R, Hussan A. Status of medicinal plants in India, some latest issues. Ann For 2000;10:181-90.

3. Janovaska D, Kubikova K, Kokoska L. Screening for antimicrobial activity of some medicinal plants species of traditional Chinese medicine. Czech J Food Sci 2003;21:107-10.

4. Dewick PM. Tumor inhibitor from plants. Trease and Evans Pharmacognosy. Philadelphia, Pa, USA: Elsevier Health Sciences; 1996.

5. Newall CA, Anderson LA, Phillipson JD. Herbal Medicines, a Guide for Health-Care Professionals. London: The Pharmaceutical Press; 1996.

6. Magherini R. Medicinal plants aromatic yesterday and today possibility of plant breeding Agricola Litalia. Indian J Biotechnol 1998;3:136-8

7. Patel I, Talathi A. Use of traditional Indian herbs for the formulation of shampoo and their comparative analysis. Int J Pharm Pharm Sci 2016;8:28-32.

8. Palomba EA, Semple SJ. Antibacterial activity of traditional Australian medicinal plants. J Ethnopharmacol 2001;77:151-7.

9. Moharram BA, Al-Mahbashi HM, Saif-Ali R, Ali Aqlan F. Phytochemical, anti-inflammatory, antioxidant, cytotoxic and antibacterial study of Capparis cartilaginea decne from Yemen. Int J Pharm Pharm Sci 2018;10:38-44

10. Khan MR, Kihara M, Omoloso AD. Broad spectrum antibacterial activity of the leaves, stem and root barks of Myristica subabulata. Nat Prod Sci 2001;7:9-15.

11. Uniyal SK, Singh KN, Jamwal P, Lal B. Traditional use of medicinal plants among the tribal communities of Chhota Bhangal, Western Himalaya. J Ethnobiol Ethnomed 2006;2:14.

12. Archana D, Dixitha M, Santhy KS. Antioxidant and anticlastogenic potential of Piper longum L. Int J Appl Pharm 2015;7:11-4.

13. Cowan MM. Plant products as antimicrobial agents. Clin Microbiol Rev 1999; 12:564-82.

14. Essawi T, Srour M. Screening of some Palestinian medicinal plants for antibacterial activity. J Ethnopharmacol 2000;70:343-9.

15. Quave CL, Plano LR, Pantuso T, Bennett BC. Effects of extracts from Italian medicinal plants on planktonic growth, biofilm production and adherence of methicillin-resistant Staphylococcus aureus. J Ethnopharmacol 2008;118:418-28.

16. Sandasi M, Leonard CM, Viljoen AM. The in vitro antibiofilm activity of selected culinary herbs and medicinal plants against Listeria monocytogenes. Lett Appl Microbiol 2010;50:30-5.

17. Guarrera PM. Traditional phytotherapy in central Italy (Marche, Abruzzo, and Latium). Fitoterapia 2005;76:1-25.

18. Nahak G, Sahu RK. Free Radical Scavenging activity of multivitamin plant (Sauropus androgynous L. Merr). Researcher 2010;2:6-14

19. Mariya P, Anto KB. Antibacterial activity of Sauropus androgynus (L.) 
Merr. Int J Plant Sci 2011;6:189-92.

20. Benjapak N, Swatsitang P, Tanpanich S. Determination of antioxidant capacity and nutritive values of Pak- Wanban (Sauropus androgynous L. Merr). KKU Sci J 2008;36:279-89.

21. Tonk S, Bartarya R, Maharaj Kumari K, Bhatnagar VP, Srivastava SS. Effective method for extraction of larvicidal component from leaves of Azadirachta indica and Artemisia annua linn. J Environ Biol 2006;27:103-5.

22. Handa SS, Khanuja SP, Longa G, Rakesh DD. Extraction Technologies for Medicinal and Aromatic Plants. United Nations Industrial Development Organization and the International Centre for Science and High Technology; 2008.

23. Harborne JB. Phytochemical Methods. London: Chapman \& Hall; 1999. p. 60-6.

24. Hameed IH, Ibraheam IA, Kadhim HJ. Gas chromatography-mass spectrum and Fourier- transform infrared spectroscopy analysis of methanolic extract of Rosemarinus officinalis leaves. J Pharmacogn Phytother 2015;7:90-106.

25. Al-Rubaye AF, Hameed IH, Kadhim MJ. A review: Uses of gas chromatography-mass spectroscopy (GC-MS) technique for analysis of bioactive natural compounds of some plants. Int J Toxicol Pharmacol Res 2017;9:81-5.

26. NIST 11. NIST Standard Reference Database 1A. NIST Mass Spectral Search Program version 2.0g. U.S. Department of Commerce, National Institute of Standards and Technology; 2011.

27. Wiley/NIST. The Wiley/NBS Registry of Mass Spectral Data. Mass Spectral Library Version 2.0. $8^{\text {th }}$ ed. New York: John Wiley \& Sons, Inc., NIST, EPA, NIH; 2005.

28. Ferrer I, Thurman ME. Liquid chromatography/Time of flight/Mass spectroscopy (LC/TOF/MS) for the analysis of emerging contaminants. Trends Anal Chem 2003;22:750.

29. ChemSpider from Royal Society of Chemistry. Cambridge. Available from: http://www.chemspider.com. [Last accessed on 2018 Jun 06].

30. Narendhirakannan RT, Nirmala JG, Caroline A, Lincy S, Saj M, Durai D. Evaluation of antibacterial, antioxidant and wound healing properties of seven traditional medicinal plants from India in experimental animals. Asian Pac J Trop Biomed 2012;2:s1245-53.

31. Eloff JN. A sensitive and quick microplate method to determine the minimal inhibitory concentration of plant extracts for bacteria. Planta Med 1998;64:711-3

32. Clinical and Laboratory Standards Institute. Performance Standards for Antimicrobial Disc Susceptibility Tests. Approved Standard CLSI Document. M100 S26. 27 $7^{\text {th }}$ ed. Clinical and Laboratory Standards Institute; 2017

33. Balouiri M, Sadiki M, Ibnsouda SK. Methods for in vitro evaluating antimicrobial activity: A review. J Pharm Anal 2016;6:71-9.

34. Stepanović S, Vuković D, Hola V, Di Bonaventura G, Djukić S, Cirković I, et al. Quantification of biofilm in microtiter plates: Overview of testing conditions and practical recommendations for assessment of biofilm production by staphylococci. APMIS 2007;115:891-9.

35. O'Toole GA, Kolter R. Initiation of biofilm formation in Pseudomonas fluorescens WCS365 proceeds via multiple, convergent signalling pathways: A genetic analysis. Mol Microbiol 1998;28:449-61.

36. Chaieb K, Kouidhi B, Jrah H, Mahdouani K, Bakhrouf A. Antibacterial activity of thymoquinone, an active principle of Nigella sativa and its potency to prevent bacterial biofilm formation. BMC Complement Altern Med 2011;11:29.

37. Huang ZR, Lin YK, Fang JY. Biological and pharmacological activities of squalene and related compounds: Potential uses in cosmetic dermatology. Molecules 2009; 14:540-54.

38. Fox CB. Squalene emulsions for parenteral vaccine and drug delivery. Molecules 2009; 14:3286-312.

39. Newmark HL. Squalene, olive oil, and cancer risk. Review and hypothesis. Ann N Y Acad Sci 1999;889:193-203.

40. Rao CV, Newmark HL, Reddy BS. Chemopreventive effect of squalene on colon cancer. Carcinogenesis 1998;19:287-90.

41. Lalitharani S, Mohan VR, Regini GS, Kalidass C. GC-MS analysis of ethanolic extract of Pothos scandens leaf. J Herb Med Toxicol 2009;3:159-60.

42. Soosairaj S, Dons T. Bioactive compounds analysis and characterization in ethanolic plant extracts of Justicia tranquebariensis L. (Acanthaceae) - Using GC-MS. Int J Chem Tech Res 2016;9:260-5.

43. Sujayil TK, Dhanaraj TS. Determination of bioactive compounds Evolvulus alsinoides leaf extracts using GC-MS technique. Res J Life Sci Bioinform Pharm Chem Sci 2016;2:31-8.

44. Dandekar R, Fegade B, Bhaskar VH. GC-MS analysis of phytoconstituents in alcohol extract of Epiphyllum oxypetalum leaves. J Pharmacogn Phytochem 2015;4:149-54

45. Rao RN, Talluri MV, Krishna TS, Ravindranath K. Continuous counter current extraction, isolation and determination of solanesol in Nicotiana tobacum L. by non-aqueous reversed phase high performance liquid chromatography. J Pharm Biomed Anal 2008;46:310-5.

46. Mathavi P, Nethaji S, Velavan. GC-MS analysis of phytocomponents in the methanolic extracts of Shorea robusta. Int J Sci Res 2015;4:1935-8.

47. Selvi SV, Baskar A. Evaluation of bioactive components and antioxidant activity of Sauropus androgynus plant extracts using GC-MS analysis. Int J Pharm Sci Rev Res 2012;12:65-7.

48. Yamuna P, Abirami P, Vijayashalini P, Sharmila M. GC-MS analysis of bioactive compounds in the entire plant parts of ethanolic extract of Gomphrena decumbens. J Med Plants Stud 2017;5:31-7.

49. Raman VB, Samuel LA, Saradhi PM, Rao NB, Krishna NV, Sudhakar M, et al. Antibacterial, antioxidant activity and GC-MS analysis of Eupatorium odoratum. Asian J Pharm Clin Res 2012;5:99-106.

50. Abdullah AS, Mirghani ME, Jamal P. Antibacterial activity of Malaysian mango kernel. Afr J Biotechnol 2011;10:18739-48.

51. Ajayi GO, Olagunju JA, Ademuyiwa O, Martins OC. Gas chromatography-mass spectrometry analysis and phytochemical screening of ethanolic root extract of Plumbago zeylanica. J Med Plants Res 2011;5:1756-61.

52. Jegadeeswari P, Nishanthini A, Muthukumarasamy S, Mohan VR. GC-MS analysis of bioactive components of Aristolochia krysagathra (Aristolochiaceae). J Curr Chem Pharm Sci 2012;2:226-32.

53. Gnanadeebam SD, Viswanathan P. GC-MS analysis of phytocomponents in Spermacoce articularis L. F. leaf. Res Pharm 2015;4:1-7.

54. Samad AP, Santoso U, Chang CS, Nan FH. Identifying and analyzing bioactive components of Sauropus androgynus ethanolic leaves extract. J Fish Soc Taiwan 2013;40:257-65.

55. Saini RK, Keum YS. Tocopherols and tocotrienols in plants and their products: A review on methods of extraction, chromatographic separation and detection. Food Res Int 2016;82:59-70.

56. Parveen S, Shahzad A, Upadhyaya A, Yadav V. Gas chromatographymass spectrometry analysis of methanolic leaf extracts of Cassia angustifolia Vahl. Asian J Pharm Clin Res 2016;9:111-6.

57. Grilo EC, Costa PN, Gurgel CS. Alpha tocopherol and gammatocopherol concentration in vegetable oils. Food Sci Technol 2014; 34:379-85

58. Kumar V, Yadav SK. Plant-mediated synthesis of silver and gold nanoparticles and their applications. J Chem Technol Biotechnol 2009; 84:151-7.

59. Edward PC, Varrid ET, Lynn RB. A Textbook of Pharmacognosy. London: Henry Kinston; 1970.

60. Trease GE, Evans WC. Pharmacognosy: A Physicians Guide to Herbal Medicine. $13^{\text {th }}$ ed. Balleiret India, London: W.R. Saunders; 1989.

61. Akiyama H, Fujii K, Yamasaki O, Oono T, Iwatsuki K. Antibacterial action of several tannins against Staphylococcus aureus. J Antimicrob Chemother 2001;48:487-91

62. Kumari M, Jain S. Review paper, Tannins: an anti-nutrient with positive effect to manage diabetes. Res J Recent Sci 2012;1:70-3.

63. Zhao AY. Development of natural antioxidant tea polyphenol. China Food Addit 2005;5:78-80.

64. Kumar PP, Kumaravel S, Lalitha C. Screening of antioxidant activity, total phenolics and GC-MS study of Vitex negundo. Afr J Biochem Res 2010;4:191-5.

65. Andarwulan N, Batari R, Sandrasari DA, Bolling B, Wijaya H. Flavonoid content and antioxidant activity of vegetables from Indonesia. Food Chem 2010;121:1231-5.

66. Badami S, Channabasavaraj KP. In vitro antioxidant activity of thirteen medicinal plants of Indian's Western Ghats. Pharm Biol 2007;45:392-6.

67. Wong SP, Leong LP, Koh JH. Antioxidant activities of aqueous extracts of selected plants. Food Chem 2006;99:775-83.

68. Ariharan VN, Devi VN, Prasad PN. Antibacterial activity of Sauropus androgynus leaf extracts against some pathogenic bacteria. Rasayan J Chem 2013;6:134-7.

69. Wei LS, Wee W, Siong JY, Syamsumir DF. Characterization of antimicrobial, antioxidant, anticancer properties and chemical composition of Sauropus androgynus stem extracts. Acta Med Litu 2011; 18:12-6.

70. Bakkiyaraj D, Pandian SK. In vitro and in vivo antibiofilm activity of a coral associated actinomycete against drug resistant Staphylococcus aureus biofilms. Biofouling 2010;26:711-7. 